\title{
Perspective
}

PERSPECTIVE Actualité en histoire de l'art

2| 2013

Brasil

\section{Porque « a história da arte no Brasil »?}

\section{Marion Boudon-Machuel}

Tradutor: Constança Vigneron

\section{(2) OpenEdition}

\section{Journals}

\section{Edição electrónica}

URL: http://journals.openedition.org/perspective/3930

DOI: 10.4000/perspective.3930

ISSN: 2269-7721

\section{Editora}

Institut national d'histoire de l'art

\section{Refêrencia eletrónica}

Marion Boudon-Machuel, « Porque « a história da arte no Brasil »? », Perspective [Online], 2 | 2013, posto online no dia 31 agosto 2015, consultado o 01 outubro 2020. URL : http://

journals.openedition.org/perspective/3930 ; DOI : https://doi.org/10.4000/perspective.3930 


\title{
Porque « a história da arte no Brasil »?
}

\author{
Marion Boudon-Machuel \\ Tradução : Constança Vigneron
}

1 Quem na França conhece a história da arte que se faz no Brasil ou da qual a arte brasileira é o objeto? É preciso admitir, apenas alguns poucos curadores e universitários. Entretanto o projeto de consagrar um número de Perspective a este país, depois da Suíça, Canadá, Grã-Bretanha, Espanha e Países Baixos, despertou um verdadeiro entusiasmo por parte dos especialistas consultados e dos membros dos comitês da revista. Este entusiasmo não tem nada de superficial, ele demonstra o interesse pelo desenvolvimento original e pelas especificidades da história da arte no Brasil. Se o historiador da arte francês souber olhar para isto, deveria felizmente, ser impulsionado e estimulado; o exemplo brasileiro poderia mesmo nos levar à novas reflexões sobre a disciplina em nosso país.

Desde o sumário deste número, cuja composição pode parecer lacunar para a periodização tradicional, a história da arte brasileira se distingue de forma talvez mais marcada do que em outros países pelo que é "história" e pelo que é "arte". Os colegas norte-americanos se localizarão sem dúvida mais facilmente nesta paisagem que contém vales - a arte medieval não existiu ali -, montes - o século XIX é um terreno muito estudado -, e até mesmo montanhas - como o da arte contemporânea -, ou que demanda um olhar diferente para objetos que não entram no campo disciplinar no senso estrito. Sobre os assuntos mais trabalhados, o especialista do velho continente é assim convidado a sair de seu quadro, a modificar o epicentro da análise e a abordar a arte dos séculos XVII, XVIII e XIX, e até mesmo dos séculos XX e XXI por uma vertente que ele pouco ou nada frequenta. Ao contrário, ele deve também procurar compreender o que pode ser uma história da arte em negativo: como ensinar a arte medieval sem obra? Como dialogar com a antropologia ou a filosofia quando estas disciplinas irmãs acolheram desde cedo objetos como os produzidos pela arte indígena, que a história da arte não soube tratar e geralmente ignorou? É preciso, como certos pesquisadores brasileiros, chegar ao ponto de considerar que a obra de arte nos períodos antigos não 
existe no Brasil, ou quase, e que então o historiador da arte brasileiro deve se limitar a participar da história da arte europeia? Estas questões atravessam o número e explicam em parte alguns artigos no limite da linha editorial de Perspective, já que ainda não é possível estabelecer balanços historiográficos onde a produção científica é ainda embrionária ou mesmo inexistente. Através dos períodos e temas abordados em profundidade, ou ao contrário, que chamam a atenção por sua ausência, é a própria disciplina que é interrogada. Já que se trata do Brasil, esta interrogação é ainda mais presente por se referir aos próprios fundamentos e estruturas da matéria. Esta última se caracteriza, na verdade, por sua extrema juventude institucional, se considerarmos como um sintoma a existência muito recente e localizada de um primeiro ciclo em história da arte. Os historiadores da arte brasileiros - é este o caso da maioria dos autores deste número - receberam primeiro uma formação de historiadores, literatos, antropólogos, sociólogos e até mesmo de economistas, e às vezes de historiadores da arte, mas neste caso fora do país. Nutridos de interdisciplinaridade, e também de internacionalidade eles têm a facilidade de um povo que conhece de fato a questão do outro e da pluralidade cultural. Estes pesquisadores, que em grande parte fizeram seus estudos fora do país, viajam muito e mantém colaborações fecundas com numerosos países. Na escala brasileira, a cartografia da disciplina é assim bastante contrastada, aqui, com uma matéria que toma a forma ainda bastante tímida de um ciclo completo ou que se afirma com força há muito tempo, mas a partir do segundo ciclo apenas, e lá, com uma coabitação com outras ciências humanas entre as quais a história da arte é apenas um ramo dependente que tem dificuldade em se impor.

Esta diversidade é reforçada por aquela dos museus e das exposições que, do museu de belas artes às bienais de arte contemporânea, passando pelos museus de história, localizados nos grandes centros ou isolados em plena floresta, constituem um terreno não menos variado da reflexão sobre o objeto da história da arte não importando qual seja a sua época de produção. Em alguns casos, o convite para pensar diferente vem da própria forma da instituição, como a notável, apesar de atípica e surpreendente mesmo para o Brasil, de um museu que expõe a produção artística passada e presente de uma minoria, lembrando a sua história, questionando sua atualidade e que, através dela, colocam perguntas que ainda dividem fortemente a sociedade. No momento em que a globalização nem sempre ajuda a história da arte a se definir, talvez o Brasil abra outras vias.

4 Este número de Perspective pretende mostrar isto: Afinal o Brasil não é uma terra tão distante, e a história da arte que se desenvolve lá, em suas semelhanças assim como em suas diferenças, poderia bem nos servir de exemplo. Seria interessante principalmente questionar a validade dos métodos e das formações norte-americanas e europeias que foram uteis aos pesquisadores brasileiros, tentando distinguir aquilo que foi ignorado daquilo que foi importado e que permitiu semear a história da arte neste país e sob que formas. Ainda é um pouco cedo para fazê-lo, mas podemos sem dúvida quantificar isto dentro de alguns anos, e por que não, graças a um segundo número de Perspective sobre o Brasil? A evolução sem precedentes que a disciplina conhece ali merece de qualquer forma, ser acompanhada de perto. 